\title{
Review of water-nanofluid based photovoltaic/thermal (PV/T) systems
}

\author{
Nur Farhana Mohd Razali, Ahmad Fudholi, Mohd Hafidz Ruslan, Kamaruzzaman Sopian \\ Solar Energy Research Institute, Universiti Kebangsaan Malaysia, Malaysia
}

\begin{tabular}{l} 
Article Info \\
\hline Article history: \\
Received Jan 28, 2018 \\
Revised May 31, 2018 \\
Accepted Jun 14, 2018
\end{tabular}

\section{Keywords:}

Electrical

Energy analysis

Exergy analysis

Solar energy

\begin{abstract}
Solar energy is secure, clean, and available on earth throughout the year. The $\mathrm{PV} / \mathrm{T}$ system is a device designed to receive solar energy and convert it into electric/thermal energy. Nanofluid is a new generation of heat transfer fluid with promising higher thermal conductivity and improve heat transfer rate compared with conventional fluids. In this review, the recent studies of PV/T using nanofluid is discussed regarding basic concept and theory PV/T, thermal conductivity of nanofluid and experimentally and theoretically study the perfromance of PV/T using nanofluid. A review of the literature shows that many studies have evaluated the potential of nanofluid as heat transfer fluid and optical filter in the PV/T system. The preparations of nanofluid play an essential key for high stability and homogenous nanofluid for a long period. The thermal conductivity of nanofluid is depending on the size of nanoparticles, concentration and preparation of nanofluids.
\end{abstract}

Copyright (C) 2019 Institute of Advanced Engineering and Science. All rights reserved.

\section{Corresponding Author:}

Ahmad Fudholi,

Solar Energy Research Institute, Universiti Kebangsaan Malaysia, 43600 Bangi Selangor, Malaysia. Email: a.fudholi@gmail.com

\section{INTRODUCTION}

The inclining population and increasing energy demand lead to decreasing current energy sources. Problems arising in environmental pollution and climate change contributed from burning fossil fuels, encourage the researchers to conduct studies in renewable energy. Malaysia is located at the equatorial, possess average hot climate throughout the year $\left(22^{\circ} \mathrm{C}-33^{\circ} \mathrm{C}\right)$, the monthly solar radiation received approximately around $400-600 \mathrm{MJ} / \mathrm{m}^{2}$. These potential factors will make this country as one of the developing country in harnessing solar energy. Solar energy has greater benefits than conventional energy due to clean energy sources, no release of pollutant, high reliability, estimated life span 20-30 years and low maintenance.

Malaysia continued to emphasis in development of renewable technology majorly in solar energy through education, research and policies. Solar energy converts to electric energy using photovoltaic technology. The cons of this pv cell are declining in efficiency conversion when temperature raised and only responsive to a portion of the solar spectrum. The solar cell conversion efficiency is in the range $6-18 \%$, which is a value measured at the Nominal Operating Temperature (NOCT) and the rest of solar radiation received are reflected and absorbed as heat energy. The low efficiency and high cost of PV cell brings the idea of hybrid PV/T. The hybrid PV/T is the integration of solar thermal collector and PV module.

The advantage of PV/T enhances the electrical energy produce, removes waste heat from $\mathrm{PV}$ module and minimized the usable space. Moreover, solar energy will convert to thermal energy as stored in air or water. PV/T collector can be classified into three categories; water PV/T collector, air PV/T collector and the combination of water/air PV/T collector. PV/T builds up from glass cover, solar cell, encapsulated materials and collector attached at the back. In terms of physical structure applied, the module could be 
classified as flat plate, concentrated and building integrated types. The absorber functions to asorb heat and simultaneously cool down the PV module. The collected heat will be in the form of air or water [1]-[10].

Nanofluid is produced by dispersing nanoparticle into basefluid with a typical size of less than 100 $\mathrm{nm}$ in a liquid. Nanofluids have been proposed as a replacement for conventional cooling fluid regards to their greatly enhanced thermal properties. Zeinali et al. [11] investigated the convective heat transfer of nanofluids in laminar flow through a channel with a square-cross section resulted in increasing heat transfer when the size of nanoparticle is smaller and volume fraction is increased. Work have been largely carried out on nanofluid for the past decades. Experiments showed a significant increase for thermal conductivity by dispersion of less than $1 \%$ volume fraction of nanofluids. The ideal thermal properties of nanofluid with higher thermal conductivity and heat transfer, smaller and compact design of PV/T will become possible without lessening the desired output.

Faizal et al. [12] calculated efficiency, size reduction, cost and embodied energy saving solar collector thermal using various metal oxide nanofluids, $\mathrm{CuO}_{2}, \mathrm{SiO}_{2}, \mathrm{TiO}_{2}$, and $\mathrm{Al}_{2}$. The short payback period, less $\mathrm{CO}_{2}$ emissions and size reduction can be achieved compared to a conventional solar collector. However the stability of nanofluid and the aggregation of nanoparticles after a certain period hindered the maximum potential of nanofluids. The physical and chemical treatment must be conducted during preparation of the nanofluids. Stability of nanofluids has a good correlation with enhancement of thermal conductivity, where the better the dispersion, the higher thermal conductivity.

Exergy analysis has become an essential tool in the system design, analysis, and optimization of thermal systems [13]-[21]. Recently, energy and exergy analysis for nanofluid based PVT systems were studied. Lari and Sahin [22] reported that PV energy efficiency was 13.2\% for PVT nanofluid system. Khanjari et al. [23] reported that PV, thermal and PV/T energy efficiencies was $10-13.7 \%, 55 \%$ and $90 \%$ respectively, and PV/T exergy efficiency was $15 \%$. However, in this review we focused on nanofluid-based $\mathrm{PV} / \mathrm{T}$ system.

\section{WATER BASED PVT SYSTEM}

The first reported study on a flat plate PV/T was presented by Wolf in 1976. Studies focusing on $\mathrm{PV} / \mathrm{T}$ collector has been carried out by other researchers since then. The result achieved by Bargene and Lovik [24] simulation showed that overall efficiency of the PV/T system could reach $60-80 \%$. Charalambus et al. [25] identified some parameters to effect PV/T perfromance such as mass flow rate, inlet temperature working fluid, number of covers, absorber to fluid thermal conductance, absorber plate and design of PV/T collector itself.

A water or nanofluid based PV/T systems as shown in Figure 1, has similar structure as the conventional flat plate solar collectors. The absorber consist of tube is attached to the PV panel in order to use for heating purposes. The water based PV/T system could achieve the enhance cooling effectiveness compared to the air based system due to the high thermal mass of the of water over the air. Zondag et al. [26] evaluated seven different designs of $\mathrm{PV} / \mathrm{T}$ water collector. The designs are categorised to sheet and tube, channel, free flow and two absorber. Although the sheet and tube design is indicated $2 \%$ less in efficiency than the channel design, it is the easiest design for manufacturing process. Thus, this design is the most promising compared to other designs
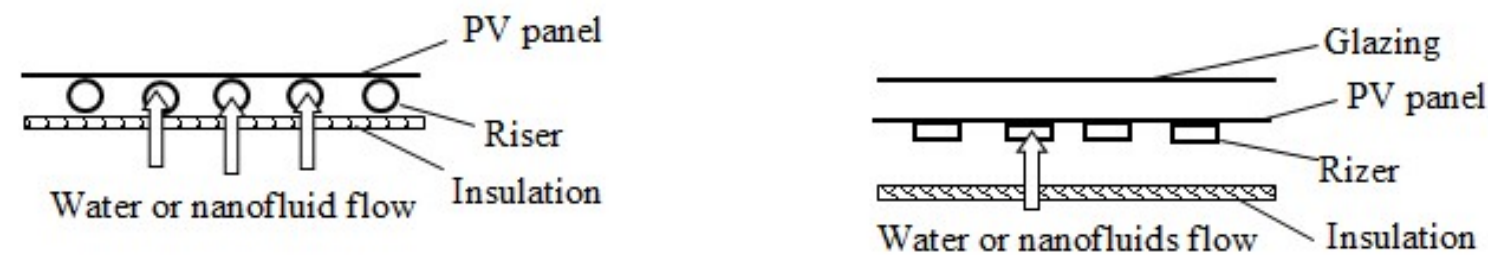

Figure 1. Flat plate water-nanofluid based PVT systems

Chow et al. [27] developed a single glazed flat plate water heating PV/T collector and discovered overall efficiency of PV/T depends on fin efficiency and the bonding collector between the collector and the sheet underneath the module. The testing of of a PV/T solar boiler with a water storage tank conducted by Zondag et al. [28] found that the covered sheet and tube system was the most promising PV/T concept for tap water heating. This PV/T system could achieve annual average solar efficiency of about $61.3 \%$. The comparison of technical characteristics of water and air based PV/T system indicated in Table 1. There are 
numerous method have been discussed in order to enhance performance of the PV/T such as suspending a thin aluminum sheet, use of fins attached to the PV rear surface and using CPC to increase the radiation falling on array of solar cells. However, the study of nanofluid as a coolant in PV/T system is a new and emphasis study must be conducted as expected interesting outcome in enhancement of PV/T overall performance.

Table 1. The Characteristics Comparison of Air and Water Based PV/T

\begin{tabular}{ccll}
\hline PV/T models & Average efficiency (\%) & \multicolumn{1}{c}{ Advantages } & \multicolumn{1}{c}{ Disadvantages } \\
\hline Air based PV/T & $24-37$ & $\begin{array}{l}\text { Low cost } \\
\text { Simple structure }\end{array}$ & $\begin{array}{l}\text { Low thermal mass } \\
\text { Large air volume } \\
\text { High heat loss }\end{array}$ \\
& \multirow{2}{*}{$33-59$} & $\begin{array}{l}\text { Poor thermal removal effectiveness } \\
\text { Still high PV temperature } \\
\text { Complex structure }\end{array}$ \\
& & $\begin{array}{l}\text { Low cost } \\
\text { High thermal mass } \\
\text { Low flow volume }\end{array}$ & PV/T \\
& &
\end{tabular}

\section{THERMAL CONDUCTIVITY OF NANOFLUIDS}

Thermal conductivity of solids and metals are higher than liquids. One of the technique proposed to increase the efficiency of thermal conductivity heat transfer fluid is a suspension of particles in fluids. Researchers conducted many experiments and theoretical studies in suspension of micro sized of particles in fluid since the published of Maxwell theoretical work. However, this method failed to be commercialized for its erosion and additional flow resistance. Choi [29] termed nanofluid, fluid suspended with nanoparticle, from his research in Agonne National Laboratory, USA. Nanofluids foreseen to be a next generation heat transfer fluids for its new exciting properties compare to pure liquids.

Thermal conductivity is the most preferable parameter to be evaluated by researchers and many experimental works recorded the result of this parameter obeservation. Thermal conductivity measured by three methods; transient hot wire, the steady state parallel plate technique and temperautre oscillation method. Since thermal conductivity is the most important parameter responsible for enhanced heat transfer many experimental work being reported on this aspect. Alumina and copper oxide are the most common nanoparticle used by many researchers in their experimental investigations.

The investigation of silica is limited compared to other nanoparticles. Temperature, particle size, dispersion and stability play an important role in determining thermal conductivity of nanofluids [30]. Das et al. examined the effect of temperature on the thermal conductivity for nanofluids containing Al2O3 and $\mathrm{CuO}$ [31]. They observed that a 2 to 4 fold increase in thermal conductivity over the temperature range of $21{ }^{\circ} \mathrm{C}$ to $52{ }^{\circ} \mathrm{C}$. Their results suggest that nanofluids is suitable for device with high energy density and work at a temperature higher than the room temperature. The remarks of enhancement in smaller nanofluids of thermal conductivity are explained by stochastic motion. Hwang et al. compared the thermal conductivity among four nanofluid (MWCNT/water, $\mathrm{CuO} /$ water, $\mathrm{SiO} 2 /$ water, and $\mathrm{CuO} / \mathrm{EG}$ ) and found the highest thermal conductivity is achieved by MWCNT up to $11.3 \%$ at 1 vol\% [32].

\section{PREPARATION OF NANOFLUIDS}

Nanofluids are produced by suspending nanometer scale solid particle into the base fluid such as water, oil and ethylene glycol. The major problem in producing nanofluid is an aggregation and inhomogeneous of colloidal suspension. The techniques for producing nanofluid are the single step and two step method. The single step early proposed by Akoh et al. [33], called as VEROS (Vacuum evaporation onto Running Oil Substrate) technique. The pro and cons of this technique is the agglomeration of the nanoparticle is minimized while on the other hand, only low vapour pressure fluids are adequate with this process. This method is highly cost and lacking in producing nanofluid in large scale. The two step method is more popular in nanofluid synthesis nowadays considering nanoparticles are able to purchase from companies. Nanoparticles are being produced as a powder and then mixed with base fluid. Ultrasonication is used to disperse nanoparticles in base fluid and reduced the agglomeration. Adding of surfactant or dispersant to nanofluid is used to attain the stability of suspension, such in experiments conducted by Murshed et al [34] and Hwang et al. [32]. Other mothed such as a $\mathrm{pH}$ value variation of nanofluid or surface active agent will change surface properties of nanoparticles except for utasonication. This is the most economic method to be practiced in industry. 


\section{NANOFLUIDS BASED PVT SYSTEMS}

The use of nanofluid as heat transfer fluid in the PV/T system proved to result in better performance. Sardarabadi et al. [35] investigated experimentally the effects of silica/water nanofluids on thermal and electrical efficiency of PV/T. The different concentration of nanofluid indicated that overal energy efficiency and total exergy increase with higher concentration of nanofluids. The efficiency PV/T equipped with a collector compared with no collector show significantly higher perfomance. Ferrofluid has unique characteristics of the rheological and thermo physical properties under an external magnetic field. Ghadiri et al. [36] evaluated the effect of ferrofluid as coolant on the overall efficiency of PV/T. The results found that $50 \%$ increase in overall efficiency when ferrofluid was placed under alternating magnetic field with $50 \mathrm{~Hz}$ frequency.

Nanofluid is applied as volumetric solar absorbers and flowing heat transfer medium in following study. Study of PV/T systems with $\mathrm{MgO}$ nanofluids applied to the top of silicon PV panel by Yun and Zhu [37] evaluated the transmittance of $\mathrm{MgO}$-water nanofluids when concentration is at $0.02 \% \mathrm{wt}, 0.06 \% \mathrm{wt}$ and $0.1 \%$ wt respectively. The inferred result is regular transmittance decrease with increase mass fraction. The electrical output of solar cells increases with lower concenctrations of nanofluid and thinner layers of nanofluid at the top of PV cells. Using one step method, Jing et al. [38] prepare of highly dispersed $\mathrm{SiO}_{2} / \mathrm{H}_{2} \mathrm{O}$ with various particle sizes. They circulate the nanofluid both above the PV panel to filter IR part of the incident light and below the PV cell to remove the heat generated in the photoeletric conversion process. This design is helpful in reduce the operation temperature of PV cell and expected to improve PV/T efficiency. Advantage of liquid filter is that they can be controlled dynamically by pumps, magnetic/electric field and temperature changes. Table 2 summarized the discussion above.

Table 2. Summary of Performance of Nanofluids Based PV/T Systems

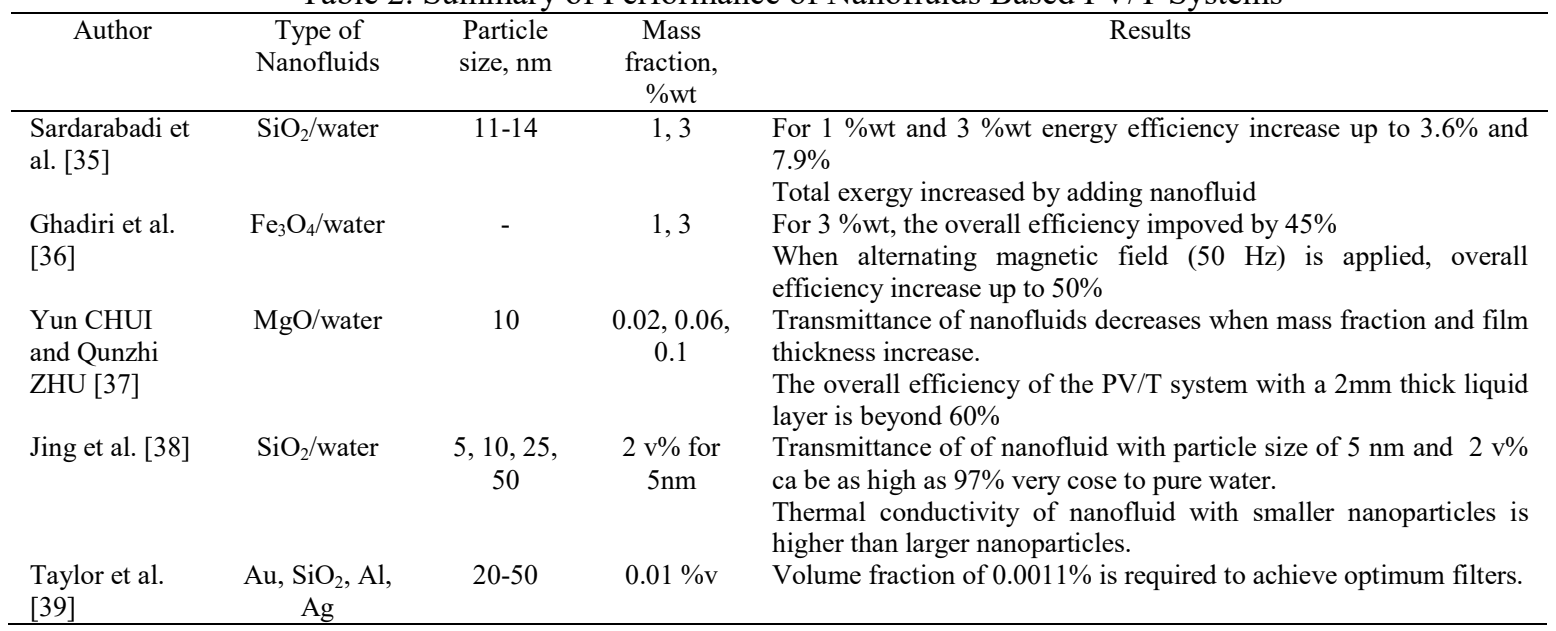

\section{CONCLUSION}

From this review it can be concluded that Nanofluid aims to replace the existing fluid due to the limitations of previous fluid in terms of thermal conductivity, heat transfer coefficient and scattering stability involving micrometer-sized particles. Effective heat transfer can increase the efficiency of PV/T system operation and power generation. Performance of $\mathrm{PV} / \mathrm{T}$ based nanofluids will increase in terms of overall efficiency compared to conventional fluid, thus smaller and compacted PV/T system using nanofluid can be manufactured. Hence it will reduce the weight, energy and cost of manufacturing. The thermal conductivity of nanofluid enhanced with smaller particle size of nanoparticles, higher volume fraction and stable nanofluid. The preparation of nanofluid is an important parameter to optimize use of superior thermal properties for practical application.

\section{ACKNOWLEDGEMENTS}

The authors would like to thank the UKM for funding (GP-K020448) and (GGP-2017-045).

\section{REFERENCES}

[1] N.S. Nazri, et al., "Energy Economic Analysis of Photo-Voltaic-Thermal-Thermoelectric (PVT-TE) Air Collectors," Renewable and Sustainable Energy Review, vol. 92, pp. 187-97, 2018.

[2] A. Ibrahim, et al., "Efficiencies and improvement potential of building integrated photovoltaic thermal (BIPVT) system," Energy Conversion and Management, vol. 77, pp. 527-34, 2014. 
[3] N.S. Nazri, et al., "Mathematical modeling of photovoltaic thermal-thermoelectric (PVT-TE) air collector. International Journal of Power Electronics and Drive Systems (IJPEDS), vol. 9(2), pp. 795-802, 2018.

[4] M. Zohri, et al., "Exergy Assessment of Photovoltaic Thermal with V-Groove Collector Using Theoretical Study," TELKOMNIKA (Telecommunication, Computing, Electronics and Control), vol. 16(2), pp. 550-57, 2018.

[5] M. Zohri, et al., "Photovoltaic Thermal (PVT) System With and Without Fins Collector: Theoretical Approach," International Journal of Power Electronics and Drive System (IJPEDS), vol. 8(4), 1756-63, 2017.

[6] A. Fudholi, et al., " R\&D of Photovoltaic Thermal (PVT) Systems: An Overview," International Journal of Power Electronics and Drive Systems (IJPEDS), vol. 9(2), pp. 803-10, 2018

[7] A. Fudholi, et al., "Review on Exergy and Energy Analysis of Solar Air Heater," International Journal of Power Electronics and Drive Systems (IJPEDS), vol. 9(1), pp. 420-26, 2018.

[8] A. Fudholi, et al., "Review On Solar Collector for Agricultural Produce," International Journal of Power Electronics and Drive Systems (IJPEDS), vol. 9(1), pp. 414-19, 2018.

[9] A. Fudholi, et al., "Primary Study of Tracking Photovoltaic System for Mobile Station in Malaysia," International Journal of Power Electronics and Drive Systems (IJPEDS), vol. 9(1), pp. 427-32, 2018.

[10] A. Fudholi, et al., "Performance Analysis of Photovoltaic Thermal (PVT) Water Collectors," Energy Conversion and Management, vol. 78, pp. 641-651, 2014.

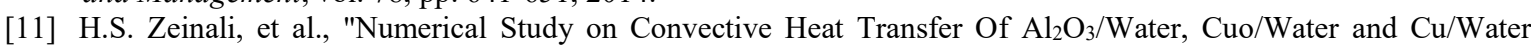
Nanofluids through Square Cross-Section Duct on Laminar Flow," Engineering Appications of Computational Fluid Mechanics, vol. 6, pp. 1-14, 2012.

[12] M. Faizal, et al., "Energy, Economic and Enviromental Analysis of Metal Oxides Nanofluid for Flat Plate Solar Collector," Energy Conversion and Management, vol. 76, pp. 162-168, 2013.

[13] A. Fudholi, et al., "Energy and Exergy Analyses of Solar Drying System for Red Seaweed," Energy and Buildings, vol. 68, pp. 121-29, 2014.

[14] A. Fudholi, et al., "Performances and Improvement Potential of Solar Drying System for Palm Oil Fronds," Renewable Energy, vol. 78, pp. 561-65, 2015.

[15] A. Fudholi, et al., "Performance Analysis of Solar Drying System for Red Chili," Solar Energy, vol. 99, pp. 47-54, 2014.

[16] A. Fudholi, et al., "Energy Analysis and Improvement Potential of Finned Double-Pass Solar Collector," Energy Conversion and Management, vol. 75, pp. 234-40, 2013.

[17] A. Fudholi, et al., "Review of Solar Drying Systems with Air-Based Solar Collectors in Malaysia," Renewable and Sustainable Energy Review, vol. 51, pp. 1191-1204, 2015.

[18] A. Fudholi, et al., "Techno-economic of Solar Drying Systems with Water Based Solar Collectors in Malaysia: a review," Renewable and Sustainable Energy Review, vol. 51, pp. 809-820, 2015.

[19] A. Fudholi, et al., "Energy and Exergy Analyses of Photovoltaic Thermal Collector with $\nabla$-groove," Solar Energy, vol. 159, pp. 742-50, 2018.

[20] M. Yahya, et al., "Energy and Exergy Analyses of Solar-Assisted Fluidized Bed Drying Integrated With Biomass Furnace," Renewable Energy, vol. 105, pp. 22-29, 2017.

[21] S.A. Kalogirou, et al., "Exergy Analysis on Solar Thermal Systems: A Better Understanding of Their Sustainability," Renewable Energy, vol. 85, pp. 1328-33, 2016.

[22] M.O. Lari and A.Z. Sahin, "Design, Performance and Economic Analysis of A Nanofluid-Based Photovoltaic/Thermal System for Residential Applications," Energy Conversion and Management, vol. 149, pp. 467-84, 2017.

[23] Y. Khanjari, et al., "Numerical Investigation on Using of Nanofluid In A Water-Cooled Photovoltaic Thermal System," Energy Conversion and Management, vol. 122, pp. 263-78, 2016.

[24] T. Bargene and O.M. Lovvik, "Model Calculations on A Fat Plate Solar Heat Collector with Integrated Solar Cells," Solar Energy, vol. 55, no.6, pp. 453-462, 1995.

[25] P. G.. Charalambus, et al., " Photovoltaic Thermal (PV/T) Collectors: A Review," Applied Thermal Engineering, vol. 27, pp. 275-286, 2007.

[26] H.A. Zondag, et al., "The Yield of Different Combined PV-Thermal Collector Designs," Solar Energy, vol. 74, pp. 253-269, 2003.

[27] T.T. Chow, "A Review on Photovoltaic/Thermal Hybrid Solar Technology,"Applied Energy, vol. 87, pp. 365-379, 2010.

[28] H.A. Zondag, et al., "The Thermal An Electrical Yield Of A PV-Thermal Collector," Solar Energy, vol. 72, no.2, pp. 113-128, 2003.

[29] S.U.S. Choi, "Enhancing Thermal Conductivity of Fluids with Nanoparticles," Development and Applicationof Non-Newtonian Flows, FED, vol. 231/MD-Vol 66, pp. 99-105, 1995.

[30] S.M.S. Murshed, et al., "A Combined Model For The Effective Thermal Conductivity of Nanofluids," Applied Thermal Engineering, vol. 29, vol. 11-12, pp. 2477-2483, 2009.

[31] S. Das, et al., "Temperature Dependance of Thermal Conductivity Enhancement for Nanofluids," Journal of Heat Transfer, vol. 125, pp. 567-574, 2003.

[32] Y. J.. Hwang, et al., "Investigation on Characteristics of Thermal Conductivity Enhancement Of Nanofluids," Current Applied Physics, vol. 6, vol. 6, pp. 1068-1071, 2006.

[33] H. Akoh, et al., "Magnetic Properties of Ferromagnetic Ultrafine Particles Prepared By Vacuum Evaporation on Running Oil Substrate," Journal of Crystal Growth, vol. 45, pp. 495-500, 1978. 
[34] S.M.S. Murshed, et al., "Enhanced Thermal Conductivity of $\mathrm{TiO}_{2}$-Water Based Nanofluids," International Journal of Thermal Sciences, vol. 44, no.4, pp. 367-373, 2005.

[35] M. Sardarabadi, et al., "Experimental Investigation of the Effects of Silica/Water Nanofluid on PV/T (Photovoltaic Thermal Units)," Energy, vol. 66, pp. 264-272, 2014.

[36] M. Ghadiri, et al., "Experimental Investigation Of A PVT Systems Performance Using Nano Ferrofluids,"Energy Conversion and Management, vol. 103, pp. 468-476, 2015.

[37] Yun, CUI and Qunzhi, ZHU, "Study of Photovoltaic/Thermal Systems with Mg/O Water Nanofluid Flowing Over Silicon Solar Cells," In: Power And Energy Engineering Conference (APEEC), Asia-Pacific Shanghai, 2012.

[38] D. Jing, et al., "Preparation of Highly Dispersed Nanofluid and CFD Study of Its Utilization in A Concentrating PV/T System," Solar Energy, vol. 112, pp. 30-40, 2015.

[39] R.A. Taylor, et al., "Nanofluid Based Optical Filter Optimization for PV/T Systems," Nature: Light Science \& Applications, vol. 1, no.34, pp. 1-7, 2012.

\section{BIOGRAPHIES OF AUTHORS}
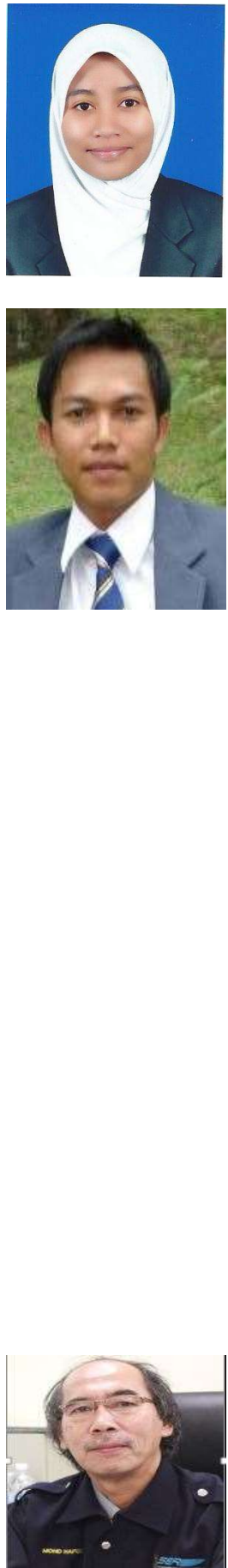

Nur Farhana Mohd Razali, M.Sc graduated with the M.Sc in Renewable Energy from Solar Energy Research Institute (SERI), Universiti Kebangsaan Malaysia (UKM), Malaysia. The M.Sc thesis was about the Exergy Analysis of Nanofluids Based Photovoltaic Thermal (PVT) Collector. Her M.Sc thesis under supervisor by Ahmad Fudholi Ph.D (main supervisor) and Prof Dr. Mohd Hafidz Ruslan (co. supervisor). She received "Excellent Thesis" Award from SERI UKM in 2017. More than 5 papers currently accepted manuscript in journals in Scopus index. She was appointed a Graduate Research Assistant (GRA) under Fundamental Research Grant Scheme (FRGS/1/2014/ST02/UKM/03/1) under project leader by Ahmad Fudholi Ph.D during his Master's degree.

Ahmad Fudholi, Ph.D, M.Sc obtained his S.Si (2002) in physics. He was born in 1980 in Pekanbaru, Indonesia. He has working experience about 4 years (2004-2008) as Head of Physics Department at Rab University Pekanbaru, Riau, Indonesia. A. Fudholi started his master course in Energy Technology (2005-2007) at Universiti Kebangsaan Malaysia (UKM). His M.Sc thesis was on Wind/PV Hybrid System and the Ph.D thesis was about the Finned Double-Pass Solar Collectors for Drying of Seaweed. His M.Sc and Ph.D thesis under supervisor by Prof Dato' Dr. Kamaruzzaman Sopian. After his master he became Research Assistant at UKM up to 2012. After his Ph.D (2012) in renewable energy, he became Postdoctoral in Solar Energy Research Institute (SERI) UKM up to 2013. He joined the SERI as a Lecture in 2014. More than USD 310,000 research grant (13 grant/ project) in 2014-2017 was involved. More than 25 M.Sc project supervised and completed. Until now, he managed to supervise $5 \mathrm{Ph} . \mathrm{D}$ (4 main supervisor and 1 Co. supervisor), 3 Master's student by research mode, and 5 Master's student by coursework mode, he was also as examiner ( $3 \mathrm{Ph} . \mathrm{D}$ and $1 \mathrm{M} . \mathrm{Sc}$ ). His current research focuses on renewable energy, especially solar energy technology, micropower system, solar drying systems, and advanced solar thermal systems (solar assisted drying, solar heat pump, PVT systems). He has published more than 100 peer-reviewed papers, which 25 papers in ISI index (20 Q1, impact factor more than 3) and more than 60 papers in Scopus index, 16 more currently accepted manuscript, 20 more currently under review, and 2 book chapters. Addition, he has published more than 70 papers in international conferences. His total citations of 756 by 493 documents and h-index of 14 in Scopus (Author ID: 57195432490). His total citations of 1363 and h-index of 19 in google scholar. He is appointed as reviewer of high impact (Q1) journal such as Renewable and Sustainable Energy Reviews, Energy Conversion and Management, Applied Energy, Energy and Buildings, Applied Thermal Engineering, Energy, Industrial Crops and Products, etc. He is appointed as reviewer of reputation journals such as Drying Technology, International Journal of Green Energy, Biosystem Engineering, Journal of Sustainability Science and Management, Journal of Energy Efficiency, Sains Malaysiana, Jurnal Teknologi etc. He is also appointed as editor journals. He has received several awards such as Gold Medal Award at the International Ibn Al-Haytham's Al-Manazir Innovation and Invention Exhibition 2011, Silver Medal Award at the International Technology EXPO (ITEX) 2012, Silver Medal Award at the Malaysia Technology Expo (MTE) 2013, Bronze Medal Award at International Exposition of Research and Invention (PECIPTA) 2011, also 2 Bronze Medal Award at PECIPTA 2017. He was also invited as speaker: Workshop of Scientific Journal Writing; Writing Scientific Papers Steps Towards Successful Publish in High Impact (Q1) Journals.

Prof. Dr. Mohd Hafidz Ruslan currently is the Deputy Director and Head of Postgrade Studies of the Solar Energy Research Institute (SERI) UKM, Malaysia. His current research focuses on solar energy, especially solar thermal technology, heat pump system, solar water heating and solar drying systems. He has published more than 150 peer-reviewed papers in ISI and Scopus index. Addition, he has published more than 100 papers in international conferences. His total citations of 1541 by 1077 documents and h-index of 22 in Scopus index (Author ID: 6504666472 ). His total citations of 2564 and h-index of 27 in google scholar index. 


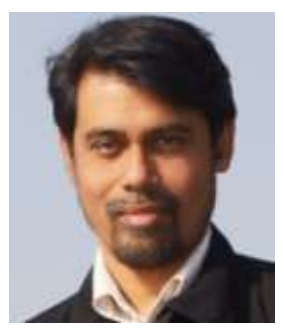

Prof Dato' Dr. Kamaruzzaman Sopian graduated with the BS Mechanical Engineering from the University of Wisconsin-Madison in 1985, the MS in Energy Resources University of Pittsburgh in 1989 and $\mathrm{PhD}$ in Mechanical Engineering from the Dorgan Solar Laboratory, University of Miami at Coral Gables in 1997. His MS thesis was on Solar Absorption Cooling System and the $\mathrm{PhD}$ dissertation was about the Double-Pass Photovoltaic Thermal Solar Collectors. Upon graduation, he has been appointed as an Assistant Professor at the Department of Mechanical and Materials Engineering, Universiti Kebangsaan Malaysia (National University of Malaysia). He was promoted to the post of Professor of Renewable Energy in the Department of Mechanical and Material Engineering, at the Universiti Kebangsaan Malaysia (the National University of Malaysia) in 2001 and currently is the Director of the Solar Energy Research Institute in the same university since 2005 . He has been involved in the field of renewable energy for more than 25-years. His main contributions are in solar radiation modeling and resource assessment, advanced solar photovoltaic systems (grid-connected photovoltaic, solar powered regenerative fuel cell, solar hydrogen production, thin film silicon solar cell) and advanced solar thermal systems (solar cooling, solar heat pump, solar assisted drying, combined photovoltaic thermal or hybrid collector). He has secure research funding from the Malaysian Minstry of Science and Malaysian Ministry of Education and industry for more than USD 6 million. He has conducted renewable enery courses the Asian School of Energy (2007 - 2014) funded by ISESCO, COMSAT, TIKA and UNESCO. He has published over 800 research papers in journals and conferences (SCOPUS $h$ index $=52$, no. of citation $=9082)($ Google Scholar $h$ index $=63$, no. of citation $=15196)$. A total of $32 \mathrm{MSc}$ (coursework), $15 \mathrm{MSc}$ (research mode) and $40 \mathrm{PhD}$ candidates from various countries such as Bangladesh, Iran, Iraq, Algreria, Libya, Indonesia, Nigeria, Oman, Yemen, Malaysia and Jordan have graduated under his supervision. He has delivered keynotes and planery speeches at national and international conferences on renewable energy in Malaysia, China, India, Iraq, Iran, France, Greece, Morroco, United Kingdom, United States, Hungary, Egypt, Libya, United Arab Emirates, Syria, Saudi Arabia, Bahrain, Indonesia, Thailand, Philiphines, Japan, Singapore, Germany, Holland, Italy, Maldives, and Combodia. He has undertaken short assignments in about 10 countries for international agencies and programs such as UNDP-GEF, UNIDO, ASEAN EU-Energy Facility, ASEANAustralia Economic Co-operation Program, ASEAN-CIDA (Canada International Development Agency), JSPS-VCC, British Council CHICHE, ISESCO and UNESCO related to renewable energy technology. He has been appointed as the Honorary Professor of Renewable Energy, at the Faculty of Built Environment, University of Nottingham, United Kingdom (2009 -2013). In addition, he has been appointed as the associate editors of the Journal of Renewable Energy (2005 - 2010) and Journal of Sustainable Cities and Society published by Elsevier Ltd, and Journal of Energy, Hindawi. Journal of Sustainable Energy and the Environment (Thailand), Jordan Journal of Mechanical and Industrial Engineering (JJMIE) (Jordan), International Journal of Thermal and Environmental (Canada) and Palestine Technical University Research Journal (Palestine). He won several international awards for his academic contribution in renewable energy including the IDB (Islamic Development Bank) S\&T Prize 2013, World Renewable Energy Network Pioneer Award 2012, Malaysia Green Technology Award 2012, and the ASEAN Energy Awards (2005, 2007, 2013 and 2014). He has 4 patents, 20 patents pending, 6 copyrights, and 1 trademark for his innovation in renewable energy technology. The innovation and invention in renewable energy technology have won 80 medals in national and international innovation and invention competitions including special innovation awards such as Prix de L 'Environnement by the Swiss Society for Environmental Protection, 2001, Geneva, Sustainable Development Award INNOVA 2007, Special Prize, Korea Invention Promotion Association at the INPEX Pittsburgh 2008 and Energy and Environmental Award, at INNOVA 2013 in Brussels. His Royal Highness The Sultan of Perak conferred the Paduka Mahkota Perak (PMP) in 2003 and the Dato' Paduka Mahkota Perak (DPMP) in 2013. He was conferred as a Fellow of the Malaysia Academy of Sciences (FASc) in 2011. Promoting renewable energy technology to the communities and industries has always been his passion. He has developed and delivered solar dryers for fish and seaweeds in Karkor Cambodia and Semporna Malaysia respectively. In addition, he has developed a cottage industry for manufacturing of photovoltaic panels in Kuala Trengganu. He has also delivered the first pico hydro system for an orang asli community in Kampung Tuel, Kelantan. He has designed and commissioned the first large scale solar assisted hot water system for a 1000 bed hospital in Malaysia and also a solar assisted drying system for old palm fronds for a palm oil factory in Malaysia. 